\title{
Peder Sjögrens världar. Om att läsa om ett författarskap
}

\section{Av Peter Forsgren}

För jämt tjugo år sedan disputerade jag på en avhandling om Peder Sjögrens 1940-talsromaner som bar titeln "Att lyssna med ögat" och där jag i tur och ordning behandlade Svarta palmkronor (1944), Kärlekens bröd (1945), Jag vill gå ned till Thimnath (1947) och Mannen som försökte smita (1949). Avhandlingens titel hade jag tagit från författaren själv. I en av de få artiklar där han beskrev sin estetik fick den synestesi som det lyssnande ögat utgör representera hans författarideal. För mig stod denna bild som symbol för det djupt dialogiska som jag menade var ett av författarskapets mest utmärkande drag. Just runt denna uppfattning utspelade sig en viss, idag sedan länge bilagd, polemik mellan mig och en annan Peder Sjögren-forskare, Anders Tyrberg, vars doktorsavhandling Skuldkänslans broderskap. En bok om Peder Sjögrens romaner kom 1996. Medan jag argumenterade för att Peder Sjögrens romaner i komposition och tematik var öppna och dialogiska och gjorde en rad, ibland lite väl långt drivna, jämförelser med den samtida Lars Ahlins och dennes så kallade förbönsestetik, relaterade Tyrberg författarens texter till en mer klassisk linje i 1900-talets modernistiska prosa som tematiserar alienation, ensamhet och kontaktlöshet. ${ }^{1}$ Olikt mig såg Tyrberg skuld som författarskapets centrala tema. Som en recensent av våra respektive arbeten mycket klokt påpekade gav författarskapet nog utrymme för båda läsningarna.

Det har hänt att jag vid ett par tillfällen plockat fram min avhandling under de två decennier som gått sedan disputationen. Vid dessa har jag gjort upptäckter som jag tror är ganska typiska: å ena sidan har jag blivit generat medveten om brister och tillkortakommanden, å andra sidan har jag också någon gång blivit positivt överraskad av saker jag hade funnit i romantexterna och lyft fram i analyserna. Peder Sjögrens romaner har jag dock inte läst om under alla dessa år, kanske för att jag under en lång tid kände mig "färdig" med dem och för att jag i min forskning kom att ägna mig åt andra texter och forskningsproblem. Under senare tid har dock gradvis en nyfikenhet vuxit fram hur det skulle vara att läsa om Peder Sjögren igen. Skulle jag känna igen mig eller skulle jag se texterna i ett nytt ljus, helt eller delvis? Skulle de överhuvudtaget hålla för en omläsning? I botten fanns säkert en rädsla att det skulle hända som ibland händer då man läser om någon favoritbok från yngre dar: förvånad undrar man vad det var man en gång såg i texten och vem den person var för vilken den en gång betydde så mycket. Vad skulle hända med Peder Sjögren och med mig vid en omläsning, var den fråga jag ställde mig. För att stilla min efterhand växande nyfikenhet valde jag att läsa om två texter som jag inte skrev om i min avhandling, romanen Damen (1951) samt långnovellen "Bikten” ur

1 Anders Tyrberg, Skuldkänslans broderskap. En bok om Peder Sjögrens romaner /Diss., Umeå/, Stockholm 1996. Se särskilt kapitlet ”Utgångspunkter”, s. 9-59. 
novellsamlingen med samma namn från 1954. Ett av skälen var att båda gjorde mycket starka intryck på mig då jag arbetade med min avhandling, ett annat var att de väl illustrerar den spännvidd i författarskapet som Anders Tyrberg och jag från olika håll försökte att lyfta fram. Jag kommer först att behandla Damen, därefter "Bikten”.

Damen anknyter motiviskt till tidigare romaner som Kärlekens bröd, Jag vill gå ned till Thimnath och Mannen som försökte smita genom att kriget på olika sätt är närvarande, antingen direkt i handlingen eller som bakgrund. I Damen rör det sig likt i Jag vill gå ned till Thimnath om det spanska inbördeskriget, medan såväl Kärlekens bröd som Mannen som försökte smita har finska vinterkriget som viktigt stoff. Av båda dessa krig hade Peder Sjögren (1905-1966) egna erfarenheter. Då inbördeskriget bröt ut i Spanien 1936 var författarens och hans familj bosatta i landet sedan flera år och vid krigsutbrottet lät Peder Sjögren genast enrollera sig på den republikanska sidan, möjligen för att inför en misstänksam omgivning visa att han som utlänning var lojal med den parlamentariskt valda vänsterregeringen. Till Finland for Peder Sjögren som frivillig vintern 1939-40. I Peder Sjögrens författarskap spelar ofta kriget och fronten rollen av reträttplats för de i livet misslyckade, för de i någon mån redan döda individerna. I synnerhet gäller detta för männen, ett tema som är ganska påtagligt även i Damen. ${ }^{2}$

Då jag nu läser om Damen är det kompositionen som först slår mig. Som vanligt rör det sig om en mycket välkomponerad roman, där inget tycks vara tillfälligt eller överflödigt. Samtidigt är skillnaden mellan tidiga romaner som Kärlekens bröd, Jag vill gå ned till Thimnath och Mannens som försökte smita också ganska påtaglig. Dessa är i samtliga fall uppbyggda kring en ramberättelse som i sin tur rymmer flera berättelser, inte sällan infällda i varandra enligt den kinesiska askens princip. ${ }^{3}$ I de två första romanerna utgörs ramberättelsen dessutom av en eller flera berättarsituationer medan Mannen som försökte smita originellt nog är berättad av ett jag som genomgående riktar sig till ett du. Det var inte minst de flytande gränserna och de metafiktiva speglingseffekterna mellan dessa olika berättelser och berättarröster, som jag hade som grund för mina dialogiskt inriktade romananalyser.

Damen är berättartekniskt organiserad på ett annat sätt. Den består av fem väl avgränsade kapitel som vart och ett har en av romanens huvudpersoner i fokus och som också bär deras respektive namn, i tur och ordning "Henry”, ”Mangle”, ”Mari”, "Påven” och "Modern”. Romanens berättare är heterodiegetisk och berättande sker från en extradiegetisk position, något som alltså skarpt avviker från berättartekniken i de tre föregående romanerna. Till skillnad från dessa så talar romanfigurerna i Damen i mycket liten utsträckning direkt med varandra och inslaget av dialog följaktligen litet i texten. I stället är det deras inre tankar som står i centrum. Dessa blir tillgängliga via berättaren med

2 Detta är tema är centralt i Kärlekens bröd, den enda av Peder Sjögrens romaner som jämte Svarta palmkronor regelbundet utkommit i nya upplagor, liksom i Mannen som försökte smita. Temat behandlas i analyserna av dessa romaner i såväl Tyrberg (1996), s. 101-138, 181-217, som i Peter Forsgren "Att lyssna med ögat". Studier i Peder Sjögrens 1940-talsromaner /Diss. Göteborg/, Göteborg 1992, s. 201-248, 301-339.

3 Särskilt utvecklat är denna form av berättande i berättandet i romanen Jag vill gå ned till Thimnath, som analyseras i Tyrberg (1996), s 139-179, och i Forsgren (1992), s. 249-299. 
hjälp av det man kallar nollfokalisering och intern fokalisering. Parallellt med att fokaliseringen växlar, blandas ofta berättarens ord med den romanfigurs ord som för tillfället är fokalisator och romanen har därför stora partier av det man kallar fritt indirekt tal. ${ }^{4}$ Härigenom uppstår enligt min mening en egendomlig paradox i denna roman: å ena sidan framstår romangestalterna som ganska isolerade och stumma, de kommunicerar sällan med varandra och när de gör detta uppstår ofta missförstånd, å andra sidan demonstrerar texten hur deras inre är uppfyllt av tankar på varandra, som det hela tiden pågick ett slags inre dialog mellan dem. Den dialog som jag fortfarande anser vara så central i Peder Sjögrens romaner, såväl berättartekniskt som tematiskt, är alltså här nästan fullständigt interioriserad. Det är också något för denna roman mycket typiskt att dialogen i romanens nästan enda berättarscen, den är i romanens slutkapitel där Henry samtalar med Mangles mor, aldrig blir någon dialog därför att en av deltagarna vid just detta tillfälle drabbas av plötslig dövhet.

Över huvud taget lever romanens gestalter i hög utsträckning främst på ett inre plan. Handlingen kretsar främst kring deras minnen och drömmar, kring deras farhågor och förhoppningar, medan den yttre handlingen likt den direkta dialogen är reducerad. Så är exempelvis fallet med romanens inledningskapitel, "Henry". Det börjar med att beskriva hur två män, Henry och en man kallad Påven, sitter i en liten båt samtidigt som de betraktas inifrån ett av hamnens hus av en kvinna vid namn Mari. Påven har fått sitt namn på grund av ett ärr i ansiktet, en detalj som ett par sidor in i texten blir utgångspunkt för en lång tillbakablick (analeps) som inleds en natt ett par år tidigare under inbördeskrigets slutskede då Henry och Påven under den republikanska arméns reträtt kommit till en i stort sett övergiven by. I ett sönderskjutet hus träffar de emellertid på en man och en äldre kvinna - den svenske farmaren Mangle och dennes mor. Påvens ärr uppkommer då Henry sparkar till honom i ansiktet för att hindra denne från att döda mannen och kvinnan.

Under krigets allra sista dagar har Henry och Påven talat om att tillsammans skaffa sig en båt, och dessa drömmar återupptar de så de återförenas några år senare efter inbördeskrigets slut. Båda männens tankar är upptagna av denna dröm, men hos Henry har det också insmugit sig en misstanke om att Påven, möjligen som hämnd, kommer att döda honom. Det är dessa ambivalenta tankar som upptar Henry på kapitlets nuplan, där de sitter i den lilla ekan, och till denna scen återkommer man i kapitlets slut. Här är Henry mycket medveten om vilka förväntningar Påven har på dem, men i stället för att svara på den vädjan han uppfattar Påven ställer till honom, förblir han tyst och överger Påven genom att i stället gå upp till Mari, något som Påven uppfattar som ett svek.

Ett annat kapitel som exemplifierar hur romanens handling huvudsakligen utspelar sig på ett inre plan och i form av tillbakablickar och minnen, är kapitlet "Mari”, som dessutom fördjupar skildringen av relationen mellan henne och de båda männen Henry och Påven. Då kapitlet börjar har det gått en tid sedan inledningskapitlets skildring av

4 För de berättartekniska termerna, se Gérard Genette, Narrative discourse. An essay in method, New York 1980 (1972), s 174, 189-194, 228 ff., 244 f. 
incidenten mellan dem i hamnen. Mari lever nu tillsammans med Henry på den farm de ärvt efter Mangle, som nyligen dött.

En natt vaknar Mari och finner att Henrys säng är tom, vilket genast väcker hennes oro. Berövad hans närvaro känner hon sig också vilsen, liksom alienerad från sig själv, vilket markeras av hur hon upplever sin kropp, närmare bestämt sina händer och fötter:

Hon lyfte omigen omedvetet opp sina händer, såg på dom och fick nåt outvecklat hjälplöst över sitt ansikte som om hon först nu förstått att hennes make kunnat ljuga för henne - ljuga om dessa oädla, kanske disharmoniska kvinnohänder. Och varför då inte också ljuga om annat?... Ljuga om större, betydelsefullare ting?...

[---]

[...] hon lyfte opp nattlinnet en smula och iakttog fötterna, kontrollerade om också de skulle servera henne en chock fast Henry naturligtvis skulle ha lett åt dom också - och nu tycktes det henne att de rödlysande, till hälften avskavda nagellacksprickarna förvandlade tårna till små runda, ganska avskyvärda miniatyrsvin, avlivade, skållade och rakade, upplagda i rad, var och en med ett öppet blodigt sår i pannan efter slaktmasken. (Damen, s 96-97)

Hon är också fylld av ambivalenta känslor gentemot Henry. Bland annat har hennes misslyckade försök att väcka hans svartsjuka vid tillfälle väckt "våldsamma hatkänslor" (Damen, s 99) gentemot honom. Hon känner sig hotad av allts som verkar vara kärt för Henry och Mari utsätter honom för olika prövningar, trots at hon älskar honom och fruktar att han skall lämna henne. Samtidigt är hon trots oron och hans frånvaro - eller kanske just därför - djupt involverad i en inre dialog med honom:

Ända sen hon slog opp ögonen hade hon varit inbegripen i ett tyst samtal med honom: alltid när han var borta från henne upplevde hon intensivt hans verkliga, påtagliga närhet. Hans röst fanns så tydlig inom henne att hon ibland måste avbryta sej under framplockandet av sina pråliga underplagg [---] Hon var uppfylld av hans person på samma sätt som under den första förälskelseperioden, uppfylld av hans lugna rörelser, hans sätt att lägga huvet på samma gång bakåt och åt sidan då han $\log$ (Damen, s. 102-103).

Det är då hon slås av tanken att Henry kan ha dött, ihjälslagen av Påven som hämnd eller förolyckad i en bilolycka, hon beger sig ut i natten för att söka efter honom. Mörkret och dimman gör att hon till sist går vilse i landskapet, som hon också upplever som allt mer fientligt. Det hela kulminerar med att hon faller till marken och skadas: "Natten själv hade slagit omkull henne och givit henne ett kok stryk.” (Damen, s. 118). Hennes relation till Henry präglas av ett starkt beroende och kärlek till honom, men också av osäkerhet, förställning och lögn från Maris sida. Till slut, alldeles innan hon fallet, vänds detta till anklagelser mot mannen:

Hennes ilska riktade sig ögonblicket efteråt i en serie snabba, hett oppflammande anklagelser emot maken. Hon sa honom rent ut där hon stod, att hon var intelligent nog att begripa att det inte var hon som var den skyldige - till hennes egna handlingar. Utan han. Att han känt till spelet inuti 
henne mycke väl. Att det var han som förlett henne, ljugit för henne i smått och stort, övat utpressning på henne med sin förbannade sävliga elegans, sin godhet, sin smärta, sitt korsfästa ansikte. Och att hon var offret. Var i hans våld - en man som hon inte kände, bara älskade. Men under den kärleken hade hon darrat: den ende som kunde skänka henne trygghet var han - och det var honom hon var rädd för. (Damen, s. 115-116)

Hon blir lugn igen först då hon överflyttar sina skuldkänslor på Påven, något som också ges en religiöst färgad innebörd för henne. Nu upplever hon inte längre landskapet som fientligt och hon kan lugnt promenera hem igen: "Över mark som inte beredde några svårigheter alls, var jämn och fast som ett golv [---] Hon frågade sig inte vilket håll hon gick åt eller hur länge hon gick. Asfalten var så skön. / Omgivningen var tom, naturen fanns inte.” (Damen, s. 120-121) Det inre samtalet med Henry fortsätter och hon föreställer sig att han lugnar och tröstar henne. Då han till sist kommer hem igen, vilket sker alldeles i kapitlets slut, låtsas hon sova och väljer att tiga, eftersom hon känner skam inför den nattliga inre dialog hon just haft med honom.

Romanen kan ses som en dialog om livet och döden, ett tema som främst bärs fram av de tre manliga huvudpersonerna, som en efter en dör. Anders Tyrberg har visat hur redan romanens omslag, som är gjort av den surrealistiskt influerade konstnären Gösta Kriland, illustrerar romanens spänning mellan dödsdrift och livsvilja, en spänning som står i centrum för hans analys av romanen. Han visar bland annat hur genomförd denna tematik är i romanen, hur den varieras och förtätas genom de olika kapitlen och romangestalterna. ${ }^{5}$ På ett för Peder Sjögren typiskt sätt har denna tematik fått ett symboliskt uttryck i den höna, kallad Damen, som både kan ge liv men som också i romanens fatala slutscen också kan vara dödande.

Även omläst framstår Damen, såväl tematiskt som berättartekniskt, fortfarande som en mycket mer "slutet" roman jämfört med de på många sätt närbesläktade romanerna Kärlekens bröd, Jag vill gå ned till Thimnath och Mannen som försökte smita. Än större är avståndet till debutromanen Svarta palmkronor, en pikareskroman som bakom sitt muntra och komiska fabulerande likväl rymmer en nog så allvarlig botten. Spänningen mellan komik och allvar, för att inte säga de ibland häftiga kasten mellan dem, är också något som omedelbart slår mig då jag också läser om långnovellen ”Bikten”, som är iscensatt i en rysk gränsby strax före världskrigets utbrott. Den ryska miljön och kulturen var något Peder Sjögren på olika sätt var bekant med och också gärna återkom till. Störst roll spelar dessa i Kärlekens bröd, där den ryske fången är något av en kristusliknande ljusgestalt som står i skarp kontrast till de krigspräglade männen vid fronten. I "Bikten” är själva utgångspunkten för handlingen en biktsituation som också utgör novellens ramberättelse: en man kommer till prästen och genast löper samtalet iväg på de mest oväntade och slingrande, mer eller mindre fantastiska banor. Den utgör en mycket intressant kontrast till den allvarstyngda ramberättelsen i Kärlekens bröd, där också rollerna mellan berättare och lyssnare är mer statiska.

5 Tyrberg (1996), s. 219-250. 
Till ”Bikten” är fogat ett författarförord, som jag skall återkomma till. Själva den hundrasidiga novellen börjar dock in medias res, mitt i ett samtal mellan biktfadern och den biktande:

- Nå, Pavel Petrovitj?

- Vodkan, fader Vassilij, det är den som är skuld till alltihop.

- Man ska aldrig dricka mer än man behöver.

- Det var inte fråga om att dricka. Det var fråga om att bränna.

- Man ska aldrig bränn... va säjer du... var det fråga om det nu?

- Det var åt er jag brände, fader Vassilij... det vet ni.

- Låt oss gå mera rakt på sak, Pavel Petrovitj... vad är det nu ni vill bikta?

- Det var då det började... alltihop... när jag gjort iordning er sista laddning.

- Vad har jag med den saken att göra... har jag inte alltid betalt ordentligt för dina tjänster?

- Jag säjer bara att dt var då det började... hela helv... hela olyckan.

- Nu är den ju i alla fall slut... både den och vodkan... vi behöver inte uppehålla oss vid det mera... ta hit huvet... här är min epitrachil... jag ger dig syndernas förlåtelse genast eftersom jag känner till hela historien i förväg.

- Det är det ni inte gör, fader Vassilij. (Bikten, s. 61)

Handlingen i den berättelse som så småningom växer fram under männens samtal skulle kunna sammanfattas på följande sätt: då Pavel Petrovitj sysslade med att bränna satte en av byns hundar i sig mäsken, varefter hunden berusad och rasande for iväg genom byn. Härigenom uppkom snart ett allt mer panikartat rykte om att byn anfallits av rabieshundar, en tolkning mannen inte gjort något för att förhindra trots att han kände till det verkliga förhållandet. Det folkliga uppståndelsen och skräcken gav i stället den enkle bonden Pavel Petrovitj i stället tillfälle att på spela hjälte och då han tillsammans med två andra män begav sig ut på jakt efter rabieshundarna omgärdades de av folkets jubel och hyllningar.

Såväl avfärden som den följande jakten med dess olika incidenter och förvecklingar skildras på ett komiskt-parodiskt sätt. Under färden genom de olika byarna, där själva jaktmotivet varvas med fester och diverse kärleksäventyr, kastas männen mellan komik och allvar, mellan upphöjelser och detroniseringar. Även relationerna och rollerna mellan de tre männen genomgår en rad förskjutningar och förvandlingar. Under färdens gång blir också gränserna mellan fantasi och verklighet alltmer flytande, även för upphovsmannen till denna fantastiska historia själv. Då berättelsen till sist nått sitt slut får likväl den biktande berättare sin välsignelse från prästen-lyssnaren.

Det komisk-parodiska präglar också ramberättelsen, det vill säga själva bikt- och berättarsituationen. Redan från början är gränserna mellan profant och heligt upplösta, och Pavels ofta slingrande berättarteknik, präglad av överraskningar och oväntade vändningar, blir vid en rad tillfällen kommenterade av prästen. Här följer ett par exempel: 
- Du får dubbla summan bara du sätter igång omedelbart.

- Med bikten?

- Nå så i alla helgons namn... sätt igång då... med bikten!

- Som sagt var... jag har redan erkänt hur det började... jag ska fatta mig kort... det var när jag brände det sista... mäsken skulle jag just till at slå bort... ni har ju själv bett mig vara försiktig med det.

- Blanda in mej så lite som möjligt, Pavel Petrovitj. (Bikten, s. 62)

- Det gläder mig att du redan hunnit ända till början, Pavel Petrovitj. (Bikten, s. 64)

- Allt ska jag klargöra fader Vassilij... ingenting ska förbli dunkelt... om ni bara ville lyssna noga...

[---]

- Va är detta för rövarhistorier? [---] Jag tror att du sitter och smäcker Pavel Petrovitj. (Bikten, s. 99, 100)

Jag vet inte längre om du sitter och driver med mej - - - (Bikten, s. 107)

Skulle jag ljuga... i biktstolen?

Det är snart inte nån biktstol längre... (Bikten, s. 151)

Samtidigt som novellen genom sin ramberättelse är genomdialogiserad, innehåller den också åtminstone en berättelse i berättelsen. Pavel bekänner att han på grund av att han älskade en av sina färdkamrater ljugit ihop en historia om hur han kommit över ett par vodkabuteljer. ${ }^{6}$ I sitt sammanhang blir denna berättelse i berättelsen ett slags mise en abyme ${ }^{7}$, ett berättargrepp Peder Sjögren tidigare särskilt använt i romanen Jag vill gå ned till Thimnat. Där liksom i novellen använt det som ett av flera grepp för att tematisera berättandet liksom fiktionens olika funktioner och möjligheter, ett metafiktivt tema som är centralt i författarskapet.

Det är heller inte särskilt svårt att se att Peder Sjögren även i "Bikten” för en diskussion om vad som är meningen med fiktion och med författare. Denna diskussion kretsar inte minst kring begreppen sanning och lögn, som bland annat framgår av följande dialog mellan den biktande och hans biktfader om möjligheten av att det faktiskt trots allt ändå kunde existera rabiessmittade hundar:

- Minns ni att jag för bara en stund sen beskrev något liknande för er fader Vassilij... som nån hade iakttagit tidigt om mornarna från Ravelins krön?

- Ja men det ljög du ju bara... det hitta du på Pavel Petrovitj!

- Det var just det som skrämde mig så... och som skrämmer mig än!

6 Denna berättelse, som utspelas bland ryska exilkretsar, går tillbaka på ett resebrev med titeln "Ryssland spökar i Ravelin”, publicerat i Dagens Nyheter 1938-03-06. Här liksom i novellen beskrivs hur dessa exilryssar lever kvar i tsartiden och hur de arrangerat sin flyktingförläggning som ett slags fiktivt S:t Petersburg.

7 Lucien Dällenbach, The mirror in the text, Chicago 1989, s. 36, definierar mise en abyme på följande sätt: "any internal mirror that reflects tho hole of the narrative by simple, repeated or 'specious' (or paradoxical duplication”. 
- Du menar att du setat och ljugit ihop själva sanningen?

- Kan Gud förlåta en människa något sådant?

- Annars skulle ju diktarna få det bekymmersamt... konstnärerna de store... de evige... inlevelsevirtuoserna själva... nå men så säj nu - - -

- Fader Vassilij... en rabiesgalen hund ... det var vad det var!! (Bikten, s. 132-133)

En ytterligare innebörd av exemplet ovan är att en berättare bara delvis har kontroll över sin egen berättelse. Andra avsnitt i deras samtal kan handla om berättelser svarar mot behovet av tröst och förklaring eller av inlevelseförmåga och gemenskap. I dessa sammanhang talas också om människans behov att både skratt och tårar. Det finna en detalj i Pavel Petrovitjs berättelse som är viktig i dessa sammanhang och det är att den hund som igångsätter hela handlingsförloppet tillhör en svensk författare som sägs tillbringa sommaren i staden. Detta pekar tillbaka till novellens författarförord, som inleds:

Denna berättelse tillägnas minnet av staden Petschori - huvudort i den $\mathrm{f}$. d. autonoma lilla rysskretsen vid Tjudskoje Ozera (Undrens sjö) som följaktligen gick under namnet Petschorski Krei - en förtjusande gammal kullerstensstad med korsvirkesstugor som nedbrann till grunden på försommaren 1939. (Bikten, s. 59)

Novellens berättelse sägs ha inträffat några dagar innan byn brann ner och en kort tid innan stadens slukades av världskrigets brand och kom att ingå i Sovjet, varifrån såväl branden som rabieshundarna sägs ha kommit enligt somliga.

Att läsa om Peder Sjögren har varit att återinträda i ett litterärt landskap som på de flesta sätt ter sig tämligen likt och välbekant, trots ett avstånd på ett par decennier då jag inte läst något av honom. Trots dessa känns författarskapet mycket välbekant för mig, kompositionsmönstren och berättarrösterna, miljöerna och symbolerna, de många konkreta detaljerna liksom också tematiken. Allt detta står åter fram mycket levande för mig och jag uppfattar fortfarande dessa texter som starka och med en tydlig appellstruktur riktad mot mig som läsare. Lusten att fortsätta läsa om författarskapet kvarstår. Nästa bok är jag särskilt nyfiken på, Peder Sjögrens sista roman Elis (1964), som börjar:

Jag Toiwo Nikkala sov inte alls för jag fick inte sova.

sådant helsikes liv som det var på kontoret den natten gubbar prata och bullra och skråla och skratt mej var det ingen som tänkte på inte att jag låg på vindsrummet över dom alltså var trött en pojke på kan väl inte va trött

en pojke på arton kan väl inte behöva att sova

i synnerhet inte en finne en grabb ifrån Haapamäki förstås som är släkting i huset och får bo där av nåd

i Finland var inbördeskrig hade varit på våren

vi hade alla gjort vårt också jag

mina båda föräldrar var skjutna (Elis, s. 9)

Romanen är skriven på ett slags rytmiserad prosa som en rad kritiker menade hade drag av hexameter men som i andra delar av boken är tydligt influerad av den radiodramatik 
Peder Sjögren skrev under 1950- och 60-talen. Utgångspunkt för handlingen är ett småländskt brukssamhälle under 1900-talets början. Peder Sjögren var född 1905 i Braås norr om Växjö där han bodde fram till sjuårsåldern och där släkten drev sågverk och glasbruk. Härifrån förflyttar sig handlingen till inbördeskrigets Finland, till Lübeck liksom till gangstermiljöer i förbudstidens Chicago. Handlingen får sin dramatiska kulmen på en strejkbrytarpråm, en miljö som också spelar en viktig roll i Mannen som försökte smita, liksom i Elis inte minst på ett existentiellt och psykologiskt plan. Som så ofta hos Peder Sjögren är även hans sista bok en berättelse om brott och skuld, men också om kärlek och försoning. På slutsidan talar åter Toiwo Nikkala, som väntar på sin avrättning. Med hans röst avslutas Elis liksom Peder Sjögrens författarskap:

i natt såg jag ut genom fönstret i cellen det var blytunga töcken däruppe belysta rakt underifrån av en storstads miljoner små ljus något mer såg jag inte

det räckte

jag hörde

det var röster ifrån dessa vältränade gråmassors djupaste inre det var röster av fåglar och de måste vart stora ett fågelstreck tror jag

deras ropande röster var ljusa och långa som natten om sommaren i Finland jag visste då genast att jag inom mig ägde allt det som de ropande bar i sitt rop

o jag gladde mig gränslöst vid tanken att snart bli en del av ett rop genom nattliga töcken (Elis, s. 172) 